GA-A16012

\title{
MEASUREMENT OF STABILITY OF CABLED CONDUCTORS COOLED BY He I AT REDUCED TEMPERATURE, OR He II
}

\author{
by \\ Y-H. HSU, J. R. PURCELL, W. Y. CHEN \\ and J. S. ALCORN
}

MASTER

\section{SEPTEMBER 1980}

\section{GENERAL ATOMIC COMPANY}




\section{DISCLAIMER}

This report was prepared as an account of work sponsored by an agency of the United States Government. Neither the United States Government nor any agency Thereof, nor any of their employees, makes any warranty, express or implied, or assumes any legal liability or responsibility for the accuracy, completeness, or usefulness of any information, apparatus, product, or process disclosed, or represents that its use would not infringe privately owned rights. Reference herein to any specific commercial product, process, or service by trade name, trademark, manufacturer, or otherwise does not necessarily constitute or imply its endorsement, recommendation, or favoring by the United States Government or any agency thereof. The views and opinions of authors expressed herein do not necessarily state or reflect those of the United States Government or any agency thereof. 


\section{DISCLAIMER}

Portions of this document may be illegible in electronic image products. Images are produced from the best available original document. 


\section{DISCLAIMER}

This report was prepared as an account of work sponsored by an agency of the United States Government. Neither the United States Government nor any agency thereof, nor any of their employees, makes any warranty, express or implied, or assumes any legal liability or responsibility for the accuracy, completeness, or usefulness of any information, apparatus, product, or process disclosed, or represents that its use would not infringe privately owned rights. Reference herein to any specific commercial product, process, or service by trade name, trademark, manufacturer, or otherwise, does not necessarily constitute or imply its endorsement, recommendation, or favoring by the United States Government or any agency thereof. The views and opinions of authors expressed herein do not necessarily state or reflect those of the United States Government or any agency thereof. 
GA-A16012

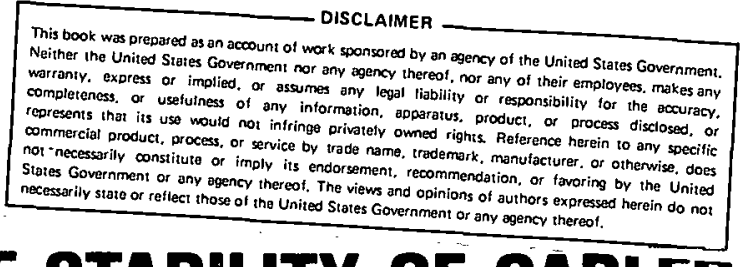

MEASUREMENT OF STABILITY OF CABLED CONDUCTORS COOLED BY He I AT REDUCED TEMPERATURE, OR He II

\author{
by \\ Y.H. HSU, J. R. PURCELL, W. Y. CHEN \\ and J. S. ALCORN
}

This is a preprint of a paper to be presented at the 1980 Applied Superconductivity Conference, September $29^{\circ}-$ October 2, 1980, Santa Fe, New Mexico.

\author{
Work supported by \\ Department of Energy \\ Contract DE-AT03-76ET51011
}

\title{
GENERAL ATOMIC PROJECT 3235 SEPTEMBER 1980
}

\section{GENERAL ATOMIC COMPANY}




\title{
MEASUREMENT OF STABILITY OF CABLED CONDUCTORS COOLED BY He I AT REDUCED TEMPERATURE, OR He II*
}

\author{
Y-H. Hsu, J.R. Purcell, W.Y. Chen and J.S. Alcorn \\ General Atomic Company \\ P.O. Box 81608 \\ San Diego, California 92138
}

\begin{abstract}
Stability tests of cabled $\mathrm{NbTi}$ alloy conductor are underway at the General Atomic High Field Test Facility, in support of the Team One effort of the DOE 12 Tesla Coil Development Program. 1 A background field of up to 10 tesla within a $20 \mathrm{~cm}$ bore is provided by a nested pair of $4.2 \mathrm{~K}$ bath cooled NbTi coils. An insulated bore insert tube (coldfinger) is provided in order to perform heat pulse/ recovery tests of coiled samples in cooling regimes anticipated for the $1 \mathrm{~m}$ O.D. coil to be tested at the LLNL 12 tesla facility during FY 82. Specifically, tests are being performed in the $2.5-3 \mathrm{~K}$ $\mathrm{He} I$, and saturated superfluid (He II) regimes. The testing apparatus, procedures, and initial results are presented.
\end{abstract}

\section{Introduction}

Team One (GA/MCA) of the DOE 12 Tesla Coil Development Program is now manufacturing conductor for a $0.4 \mathrm{~m}$ I.D. $x 1 \mathrm{~m} \mathrm{O.D.} \mathrm{superconducting} \mathrm{coil,} \mathrm{to} \mathrm{be} \mathrm{tested} \mathrm{during} \mathrm{FY} 82$ at the LLNL High Field (12 T) Test Facility. The cabled NbTiTa alloy, $10 \mathrm{kA}$ conductor is prototypical of that envisioned for the high field region of an ETF toroidal field coil. Helium bath cooling would be employed; either $\mathrm{He} \mathrm{I}$ in the $2.5-3 \mathrm{~K}$ range, or saturated superfluid $\mathrm{He}$ II at around $1.8 \mathrm{~K}$.

A testing program is presently underway at General Atomic to support and augment this effort by performing heat pulse/ recovery tests on coiled samples of cabled conductor in the selected cooling regimes. The goal of these tests is to guide the cryogenic design of the large test coil, and to provide a decpencd understanding of the conductor/coil/coolant parameters to be encountered during the subsequent large coil tests at LLNL. The GA test apparatus and procedures are presented, as well as results of initial tests.

\section{Experimental Arrangements}

A test facility has been established at GA having the capability of generating 10 tesla within the $20 \mathrm{~cm}$ bore of its nested solenoid pair (Fig. 1). 2 Both background field coils employ NbTi; the $40 \mathrm{~cm}$ bore 8 tesla coil, built by MCA, is intrinsically stable, and without internal cooling; the Insert coll was "diy" wound by GA using "barber pole" wrapped cable, supported by stainless steel strip wound on its. O.D. Both coils arc cooled by pool boiling at $4.2 \mathrm{~K}$. The experiments at sub-4.2 $\mathrm{K}$ temperatures are performed in a separatc bath within a vacuum insulated tube (coldfinger), inserted within the $20 \mathrm{~cm}$ bore. Figure 2 shows the experimental arrangement inside the coldfinger. A sealed insulated barrier with an opening of $5 \mathrm{~cm}$ is located in the coldfinger above the experimental section to prevent excessive heat leak during superfluid operation. Helium I is used to intercept the principal heat leaks, and serves as a reservoir of coolant for the experimental section. The line from the He I bath to the experimental scction serves both as a fill and a liquid makeup line through a remotely actuated J-T valve. The screens (supported by phenolic sheets) are used as heat exchangers. The temperature of the bath in the experimental section is controlled by the pumping speed (pressure). Only the saturated pressure cases are presented here. The setup in the coldfinger can be modified for testing samples at subcooled conditions.

Work supported by the Department of Energy, Contract DE-AT03-76ET51011.

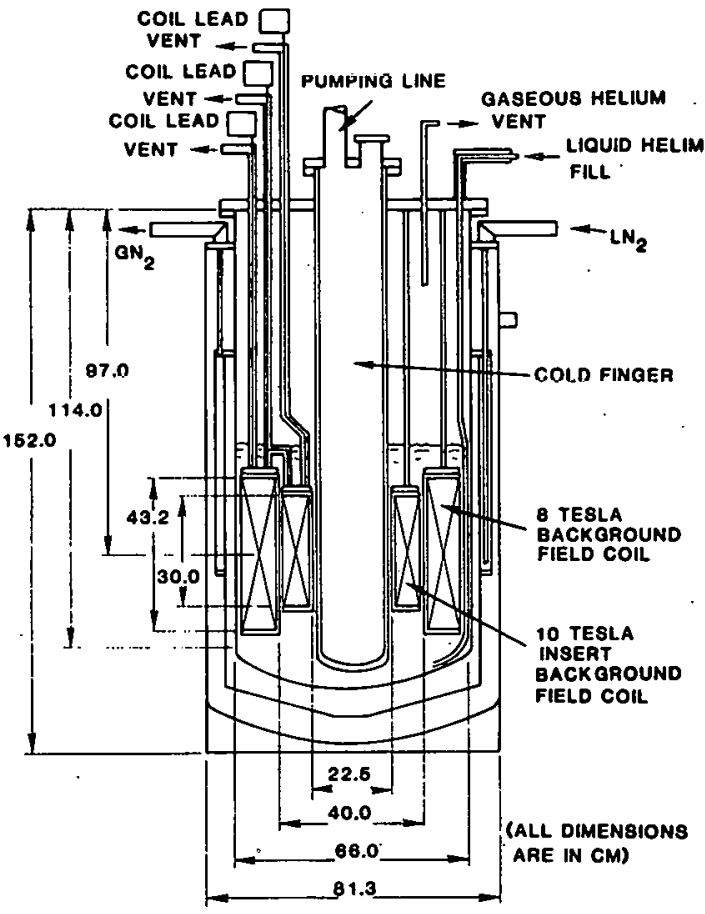

Fig. 1. Coil/cryostat cross section

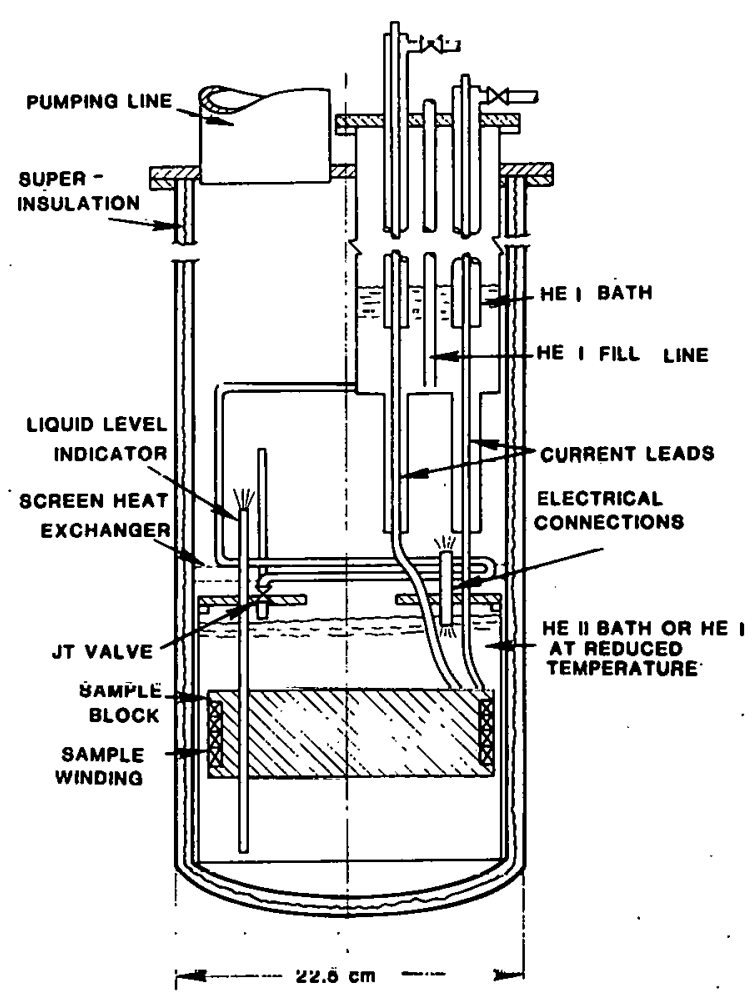

Fig. 2. Cross section of coldfinger 
For the test sample shown, $85 \mathrm{~cm}$ of a multifilament $\mathrm{NbTi} / \mathrm{Cu}$ cabled conductor from Supercon is bifilar wound as a single layer on a phenolic winding form. The conductor is insulated from adjacent conductors by a fiberglass strip; about $50 \%$ of its surface is exposed for cooling.

The heater element consists of a 10 mil diameter uninsulated nichrome wire wound around the conductor over a length of about $2.5 \mathrm{~cm}$. The heater is insulated from the conductor by a layer of mylar. Additional insulation was applied over the heater element to reduce the heat flow from the heater to the helium bath. The duration of the heat pulse is controlled by the minicomputer PDP11/ 03. The voltage taps are uniformly spaced on the conductor. The axis of the sample is parallel to the field and is vertical.

\section{Experimental Procedure}

The test sample was placed in a constant external field and cooled by pool boiling to $4.2 \mathrm{~K}, 2.5 \mathrm{~K}$ or $1.8 \mathrm{~K}$. For the stability test, a thermal disturbance was induced by a rectangular heat pulse and the evolution of the normal zone then monitored by observing the voltage across the various voltage taps along the conductor. The data was recorded by the computerized data acquisition system and displayed on a screen. (The recovery current was defined as the maximum current which allowed recovery of full superconductivity after the heat has been turned off.) Measurements are carried out on multifilamentary $\mathrm{NbTi}$ cabled conductors which are: (1) as formed; (2) solder-filled with $\mathrm{Sn}-50 \mathrm{~Pb}$ solder. The characteristics of the sample are listed in Table 1.

TABLE 1

CHARACTERISTICS OF THE CONDUCTOR TESTED

Supplier. . . . . . . . . . . . . . . . . Supercon Configuration . . . . . . Rectangular unsoldered cable Size ................ $0.500 \mathrm{~cm} \times 0.254 \mathrm{~cm}$

Number of strands. . . . . . . . . . . . . . . 18 Twist pitch . . . . . . . . . . . . Strand:

Material ........................

Size $\ldots \ldots \ldots \ldots \ldots \ldots \ldots \ldots \ldots .0 .086 \mathrm{~cm}$ diametor

Number of filaments ...................54

$\mathrm{Cu} / \mathrm{Sc}$ ratio . . . . . . . . . . . . . . . . . 1

Short sample current....... 750 A at $10 \mathrm{~T}$ and $4.2 \mathrm{~K}$

\section{Experimental Results and Discussion}

Figure 3 is a typical plot of the differential voltage as a function of time. Results of recovery current at various temperatures and fields are summarized in Table 2.

The following observations were made:

1. The recovery current at $2.5 \mathrm{~K}$ is lower than $4.2 \mathrm{~K}$; although the critical current is higher at $2.5 \mathrm{~K}$. It implies that cooling is worse at $2.5 \mathrm{~K}$, i.e., the surface heat transfer is poorer at $2.5 \mathrm{~K}$ than at $4.2 \mathrm{~K}$ as expected from surface heat transfer experiments. 3,4

2. As anticipated, the recovery current with superfluid cooling is much larger than that with He I. Part of this improvement can be attributed to the highcr critical current density; however, the largest effect is the good surface heat transfer characteristics of He II.

3. The conductor is well compacted. Taking the wetted perimeter as $50 \%$ of uules eiriclosurc, the hoat flux rate at $4.2 \mathrm{~K}$ is then $0.446 \mathrm{watt} / \mathrm{cm}^{2}$. This is about half of the maximum nucleate boiling rate.

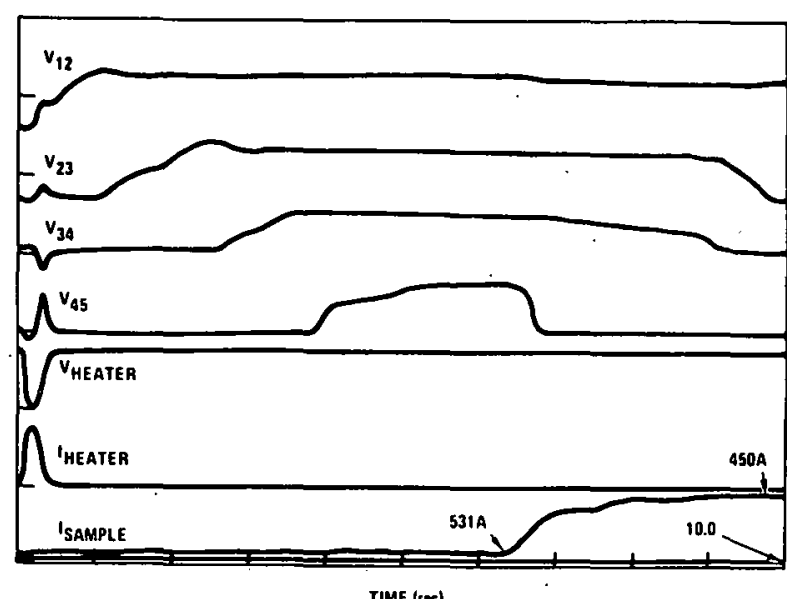

TIME (sec)

Fig. 3. Typical plot of differential voltage over the sample. The sample current was manually reduced after 6.5 seconds. (July 17, 1980,Supercon cable, $2.5 \mathrm{~K}, 8 \mathrm{~T}$ )

TABLE 2

RECOVERY CURRENT FOR VARIOUS TEMPERATURES AND FIELDS

\begin{tabular}{|c|c|c|c|c|c|}
\hline No. ${ }^{(\mathrm{a})}$ & $\begin{array}{c}\mathrm{T} \\
(\mathrm{K})\end{array}$ & $\begin{array}{c}\mathrm{B} \\
(\mathrm{T})\end{array}$ & $\begin{array}{c}\mathrm{E}^{(\mathrm{b})} \\
(\mathrm{mJ})\end{array}$ & $\begin{array}{c}\mathrm{I}_{\text {Recovery }} \\
\text { (Amperes) }\end{array}$ & $\frac{\text { Watt }^{(\mathrm{c})}}{\text { cm Length }}$ \\
\hline 1 & 4.2 & 8 & $2000^{(\mathrm{d})}$ & 575 & 0.316 \\
1 & 2.5 & 8 & $2000^{(\mathrm{d})}$ & 475 & 0.216 \\
1 & 1.89 & 8 & $2000^{(\mathrm{d})}$ & 850 & 0.691 \\
1 & 1.8 & 9 & $2000^{(\mathrm{d})}$ & 800 & 0.672 \\
2 & 2.0 & 9 & $2000^{(\mathrm{e})}$ & 750 & 0.538 \\
2 & 1.77 & 9 & $1750^{(\mathrm{c})}$ & $>900$ & $>0.77 \mathrm{~S}$ \\
\hline
\end{tabular}

(d) Sample No. 1 is cabled conductor as formed. Sample No. 2 is solder-filled cabled conductor.

(b) Disturbance energy.

(c) Heat generation rate in the normal region, assuming uniform current distribution.

(d) Heat pulse duration $=0.2 \mathrm{sec}$.

(e) Heat pulse duration $=1.0 \mathrm{sec}$.

4. All the operating currents in the sample are well below the critical current. The normal zone propagation velocities are in the few $\mathrm{cm} / \mathrm{ses}$, range.

5. For the solder-filled sample, we encountered a shorted heater, so the experimental data only gives qualitative behavior. It does show that the recovery current is smaller than the cabled conductor under the same condition, but is larger than that at $4.2 \mathrm{~K}$.

6. The double step behavior of differential voltage, as mentioned by S.W. Van Sciver and O. Christianson, ${ }^{5}$ was sometimes seen in our data.

Further investigation is necessary. 


\section{Conclusions}

Tests performed to date emphasize the relative ease of operating with saturated superfluid helium. Preliminary heat pulse/ recovery tests confirm the greatly improved conductor stability performance in the $\mathrm{He}$ II regime, relative to operation at $2.5-3 \mathrm{~K}$. Both results point to the desirability of seriously considering employment of NbTiTa alloy, bath cooled with saturated superfluid helium for large coil applications.

Further samples are being prepared for systematic quantitative study of cabled NbTi alloy conductor, bath cooled with $\mathrm{He} \mathrm{I}$ in the 2.5-3 $\mathrm{K}$ range, and with saturated superfluid helium.

\section{References}

1. J.S. Alcorn, J.R. Purcell, W.Y. Chen and Y-H. Hsu, "Status of the GA/MCA 12 Tesla Coil Development Program," Paper HA-6 presented at this conference.
2. M. Otavka, J. Alcorn, J. Purcell, W. Chen and W. Toffolo, IEEE Transactions on Magnetics, Vol. MAG-15, No. 1, 46 (1979).

3. V.I. Deer, V.E. Keilia, I.A. Kovalev, A.K. Kondratenko and V.I. Petrovichev, Cryogenics, 557 (1977).

4. E. Ibrahim, "A Study of Pool Boiling Heat Transfer to Subcooled Liquid Helium," Ph.D Thesis, University of Wisconsin (1977).

5. S.W. Van Sciver and 0 . Christianson, IEEE Transactions on Magnetics, Vol. MAG-15, No. 1, 744 (1979). 


\section{INTERNAL DISTRIBUTION}

J. Alcorn

S. Burnett

W. Chen

V. Cravens

J. Dow

E. Hoffmann
$\mathrm{Y}-\mathrm{H}$. Hsu

H. Loftstedt

D. Mery

T. Ohkawa

J. Purcell

\section{EXTERNAL DISTRIBUTION}

Don Beard

Component Development Branch

Division of Development and Technology Office of Fusion Energy, MSG-234

Washington, D.C. 20545

R.W. Boom

531 E.R.B.

University of Wisconsin

, 1500 Johnson Drive

Madison, Wisconsin 53706

Dr. Rudi Brogli

Swiss Federal Institute for

Reactor Research, E.I.R.

$\mathrm{CH}-5305$ würenlingen, Switzerland

Mr. Donald N. Cornish

Lawrence Livermore Laboratory

P.O. Box $808, \mathrm{~L}-550$

Livermore, California 94550

L. Dresner

Oak Ridge National Laboratory

P.0. Box $Y$

Oak Ridge, Tennessee 37830

W.A. Fietz

9204-1/MS-14

Oak Ridge National Laboratory

Oak Ridge, Tennessee 37830

J. File

Princeton Plasma Physics Laboratory

Princeton University

P.0. Box 451

Princeton, New Jersey 08540
P.N. Haubenreich

Oak Ridge National Laboratory

P.0. Box $Y$

Oak Ridge, Tennessee 37830

M. 0. Hoenig

NW14-2219A

Massachusetts Institute of Technology

150 Albany Street

Cambridge, Massachusetts 02139

M.S. Lubel1

Oak Ridge National Laboratory

P.O. BoX Y

Oak Ridge, Tennessee 37830

Dr. A. Hilary Morton

Plasma Research Laboratory

Australian National University

Canberra ACT 2500, Australia

Dr. E.S. Weibel

Ecole Polytechnique Federal de Lausanne CH-1007 Lausanne

$21 \mathrm{Av}$. des Bains, Switzerland

J.E.C. WIlliams

Massachusetts Institute of Technology

150 Albany Street

Cambridge, Massachusetts 02139

Dr. Li Zhengwn, or Dr. Sun Xiang

Southwestern Institute of Physics

P.O. Box 15

Leshan, Sichuan

People's Republic of China 
GENERAL ATOMIC COMPANY P. O. BOX 81608

SAN DIEGO, CALIFORNIA 92138 